\title{
Herd simulation model of muturu cattle under sedentary pastoral farming in derived savannah, Southeast, Nigeria
}

Nweze, B. O. and Otuma, M. O.

Department of Animal Science, Ebonyi State University, Abakaliki

Corresponding author: obasinweze@gmail.com; +2348037466742

\section{Abstract}

Herd simulation model was adopted to assess the productivity of Muturu cattle under sedentary pastoral system within southeast, Nigeria. The model involved biomass and other productivity investigations of the Muturu herds on field-gazed and stall-fed management within the wet and dry season period. Biological entities of Muturu herds from 500 Muturu cattle holders (MCH) and Non-Pastoral holders (NPH) surveyed from year 2010 to 2019 were studied. The sedentary production system was simulated and statistically analyzed. The results showed 70 percent MCH and 30 percent NPH, with60 percent of the Muturu stock sourced through donation/leasing arrangement by the NPH, while only 5 percent of the stock for the study was through purchase arrangement by the MCH. Sedentary pastoral system in southeast Nigeria operates at a very low commercial level. There were significant differences $(P<0,05)$ in some of the biological entities such as live weight at 12 and 24 months, which were better in the wet season than in the dry season. The stall-fed management was relatively better than the field grazed management. Simulated values were higher than the actual values in some of the biological entities but fit in with field grazed and stall-fed management. The efficiency of Livestock/forage production under the sedentary system was very low with 13.02, 15.32 and 17.35 percent respectively for field-grazed, stall-fed management and simulation model. The herd biomass and productivity values of Muturu herd under the sedentary pastoral system in the Southeast region were very low with 25.00 and 33.33 percent for field grazed and stall-fed management respectively.

Keywords: Sedentary, Pastoral Farming, Muturu Cattle, herd simulation, derived savannah.

\section{Un Modèle de simulation de troupeau de bovins muturu sous élevage pastoral sédentaire dans la savane dérivée au sud-est duNigeria}

Nweze, B. O. et Otuma, M. O.

Department of Animal Science, Ebonyi State University, Abakaliki

Corresponding author: obasinweze@gmail.com; +2348037466742

\section{Résumé}

Un modèle de simulation de troupeau a été adopté pour évaluer la productivité des bovins Muturu sous système pastoral sédentaire dans le sud-est du Nigeria. Le modèle impliquait des études sur la biomasse et d'autres études de productivité des troupeaux de Muturu sur la gestion surveillée sur le terrain et nourrie en stabulation pendant la période de saison humide et sèche. Les entités biologiques des troupeaux Muturu de 500 éleveurs Muturu (le 'MCH') et non pastoraux (le 'NPH') enquêtés de 2010 à 2019 ont été étudiées. Le système de production sédentaire a été simulé et analysé statistiquement. Les résultats ont montré 70 pour cent de 'MCH' et 30 pour cent de 'NPH', avec 60 pour cent du stock de Muturu provenant d'un accord de don / location par le 'NPH', tandis que seulement 5 pour cent du stock de l'étude provenait d'un accord d'achat par le 'MCH'. Le système pastoral sédentaire du sud-est du Nigéria fonctionne à un niveau commercial très bas. Il y avait des différences 


\section{Herd simulation model of muturu cattle under sedentary pastoral farming}

significatives $(P<0,05)$ dans certaines des entités biologiques telles que le poids vif à 12 et 24 mois, qui étaient meilleures pendant la saison des pluies que pendant la saison sèche. La gestion des étables était relativement meilleure que la gestion des pâturages sur le terrain. Les valeurs simulées étaient plus élevées que les valeurs réelles dans certaines des entités biologiques, mais cadraient avec la gestion des pâturages sur le terrain et des stalles. L'efficacité de la production de bétail / fourrage dans le système sédentaire était très faible avec 13,02, 15,32 et 17,35 pour cent respectivement pour le modèle de gestion et de simulation sur pâturage au champ, en stabulation. Les valeurs de la biomasse et de la productivité du troupeau deMuturu sous le système pastoral sédentaire dans la région du Sud-Est étaient très faibles avec 25,00 et 33,33pour centrespectivement pour la gestion des pâturages au champ et des stalles.

Mots clés : Sédentaire, élevage pastoral, bovins Muturu, simulation de troupeau, savane dérivée.

\section{Introduction}

Muturu breed of cattle, which is one of the indigenous non-zebus, shorthorn cattle found in the Southern and North Central, Nigeria is at the verge of extinction. The cattle population estimated at 0.76 percent of Nigerian indigenous breed (Payne, 1990) continued dwindling on yearly basis due to poor pastoral farming system and lack modern cattle facilities. Reports have indicated that Muturu cattle rearing are becoming unattractive for commercial purpose particularly in the Southeast region probably due to small herd size and poor productive capacity (Nweze, 2006, Nweze and Ekwe, 2012). The cattle have relatively smaller body size and lower milk yield than other Nigerian indigenous breed such as N'dama, White Fulani cattle, etc (Fricke, 1993 and Payne, 1990). Despite these limitations for Muturu cattle, it has been reported that the breed is hardy and with reasonable tolerant to trypanosomiasis disease (Payne, 1990). Muturu breed is popular cattle among the Igbo speaking tribe of Nigeria. The "Efi-igbo" as called by the natives of Southeast, Nigeria is highly regarded customarily for ceremonial activities such as traditional rites, title taking, naming ceremonies, burial and marriage rites (Nweze, et al., 2002).

A popular production system of Muturu cattle in Southeast region is sedentary pastoral farming, characterized by subsistent or semi-subsistent small size holding of herd under low input management (Fricke, 1990 and Nweze, 2017). Under this pastoral system, the cattle is common property in which the owner of stock has no regard for the livestock as a business venture and with no serious management effort put in place during the production process. This situation usually results into a very low output from the animal. In addition to this, other cattle rearing challenges arise due to improper diseases and pest control management, poor feeding, breeding and inadequate housing management. In some cases, seasonal tethering and field grazing under the control of children occur. Muturu cattle roam within the neighborhood, scavenging in some villages within the zone without any proper record kept for the Livestock (Nweze, 2003). The sedentary pastoral system is unpopular within southeast region due to little economic benefit. It cannot fit into the modern cattle production system because of low patronage by investors. It lacks the capacity of engaging the youth as a reliable means of livelihood.

One of the major attributes of this pastoral system is that of socio-cultural emphasis on royalty rather than the real economic value that is worthy of means of livelihood. Within societal setting of many southeast villages, Muturu cattle production is not a lucrative business venture even as it is a 


\section{Nweze and Otuma}

highly capital intensive enterprise and therefore the livestock farming is not worthy of any attention. Moreover, the pastoral system does not even give room for proper assessment of the Livestock/forage resources within the region. Furthermore, there is overstretched land space due to developmental activities as well as the use of land for other agricultural and nonagricultural purposes in many part of Southeast region. These factors make the operation of pastoral system difficult (Apata et al., 2011). There are unusual clashes between pastoralists and crop farmers (Nweze, 2017 and 2008) as well as competition for land resources between the pastoral farming and arable cropping. These complex challenges need a model that can assess feedback effect of livestock/forage resource. Assessment of herd-unit-economy of Muturu cattle is necessary under this traditional livestock husbandry system to define the future of cattle production in this region.

In view of the above situation, herd simulation model involving the use of integer, stochastic, non-optimizing and type dynamic system (Krumel et al., 1986) to evaluate the productivity of Muturu cattle under the rural sedentary production system is necessary. The forage potential in response to animal activities within the savannah region requires a study that should provide feedback mechanism (Agyemang et al; 1996). The assumption under this model is that there is sufficient forage resources that can sustain the biological activities of cattle herd with the corresponding economic benefit under the existing pastoral system. The study looked at the qualitative description of Muturu cattle productivity at the beginning of simulation with the input at the initial herd biomass, the production processand the output at the final herd biomass at the end of simulated period. The production processes specified the conditions, management regimes and alternative production strategies as well as stipulates a consistency check and other assessment methods.

\section{Materials and methods \\ Location of study}

The study was conducted at Savannah region Southeast, Nigeria lying on longitude $060^{\circ} 4^{\prime} \mathrm{N}$ and latitude $080^{\circ} 65^{\prime}$ (Lawson, 1980). The weather condition is considerably a bi-modal rainfall pattern, occurring around June-July and SeptemberOctober. The wet season is usually around March-April and last up to December with mean rainfall and temperature of $1250 \mathrm{~mm}$ and $28^{\circ} \mathrm{C}$ respectively and 75 percent humidity. Late December to early March is the dry season, characterized with low humidity, dry forage materials and bush burning of the surrounding environment. The forage materials are mainly annual, perennial grasses, legumes and scattered bushes of trees and shrubs that are hardly accessible to cattle. There is availability of abundant forage species during wet season.These forage materials mature rapidly and decline digestible nutrients within a short period of wet season (Umunna and Isi, 1993). Table 1 represents the forage characteristics of the area (Nweze, 2017).

Table 1: Forage characteristic of the derived savannah region

\begin{tabular}{lll}
\hline Parameters & Wet Season & Dry Season \\
\hline Feed type & grasses/legumes/browses & fodder/agro-by-products/pasture \\
Feed availability & very high - high & low - very low \\
Digestible nutrient(\%) & $68.00-5.50$ & $52.00-48.00$ \\
Animal mobility & low & High \\
Disease and pest & high - low & Low \\
Water availability & high & Low \\
Grazing time & high & low \\
\hline
\end{tabular}

Sources: Nweze, 2017 


\section{Herd simulation model of muturu cattle under sedentary pastoral farming}

\section{Experimental procedures}

There were two type of Cattle holdings in this study, namely Muturu cattle holders (MCH) and Non-pastoral holders(NPH). NPH are wealthy men, politician, traditional rulers, etc, that own one or more cattle as stockholder but are not able to keep them and manage but give the cattle for other people $(\mathrm{MCH})$ to manage for them.

A survey conducted in which structured questionnaires and group interview were administered to cattle stockholders within communities of five states of Ebonyi, Enugu, Abia, Anambra and Imo that makes up the Southeast Geo-political zone involved. $200 \mathrm{MCH}$ and $\mathrm{NPH}$ who were randomly drawn from five local government areas in each state. The data collected from year 2010 to 2019, validated and analyzed using a secondary data from previous studies were involved in the model (Nweze et al., 2013).

\section{Validation process}

The validation process involves herd identification, spot observation and assessment of biological entities from the herd gotten from MCH and NPH. The birth rate of the herd was assessed using the expression represented below (Andrezejewske, 1992).

$$
\begin{aligned}
& \text { b }=\frac{R N_{\mathrm{F}} 100}{W_{\mathrm{b}}} \mathrm{k}=\text { biological process } \\
& \mathrm{N}_{b}=\text { total breeding cows }
\end{aligned}
$$

Where $b=$ birth rate $\quad \mathbb{N}_{\mathrm{I}}=$ number of cow that calved at time ( 365 days).

Biological process $(k)$ involved

$$
\begin{aligned}
& \text { Litter size ( } \mathrm{L} \text { ) }=1 \text { Calf } \\
& \text { Study period (T) = } 365 \frac{1}{4} \text { days } \\
& \text { Muturu gestation period }\left(t_{p}\right)=280 \text { days } \\
& \mathrm{K}=\frac{L T}{t p}=1.30 \\
& \mathrm{~b}=\frac{1 \mathrm{ag} \mathrm{N}_{\mathrm{c}}, 100}{\mathrm{Mb}_{\mathrm{b}}}
\end{aligned}
$$

The mortality and survival rates of the Muturu herd were analyzed using the expression below

$$
\mathrm{d}=\frac{N_{0}+N_{\mathrm{t}}-N_{1} 100}{N_{b}}
$$

Where $\mathrm{d}=$ death rate, $\mathrm{N}=$ total number of cattle in the herd, $\mathrm{N}_{\mathrm{s}}=$ initial number of cattle in the herd, $\mathbb{N}_{\mathrm{L}}=$ number of new animal in the herd at ( $\mathrm{T}$ period $=365 \frac{1}{4}$ days).

$$
\begin{array}{ll}
\mathrm{S}=\frac{N+N_{t}-N_{\mathrm{a}}=100}{N} & \text { where } \mathrm{S}=\text { Survival rate } \\
\mathrm{D}=\mathrm{d}_{\mathrm{s}} / \mathrm{d}_{\mathrm{t}} \geq 1 & \mathrm{~N}=\mathrm{Number} \text { of cattle at end of } \mathrm{T}=365 \frac{\mathrm{g}}{4} \mathrm{days} \\
& \mathrm{N}_{\mathrm{b}}=\text { Number of births and } \\
& \mathrm{N}_{\mathrm{s}}=\text { Number of animals that died }
\end{array}
$$




\section{Nweze and Otuma}

Muturu simulation process

Figure 1 shows the components of biological entities.

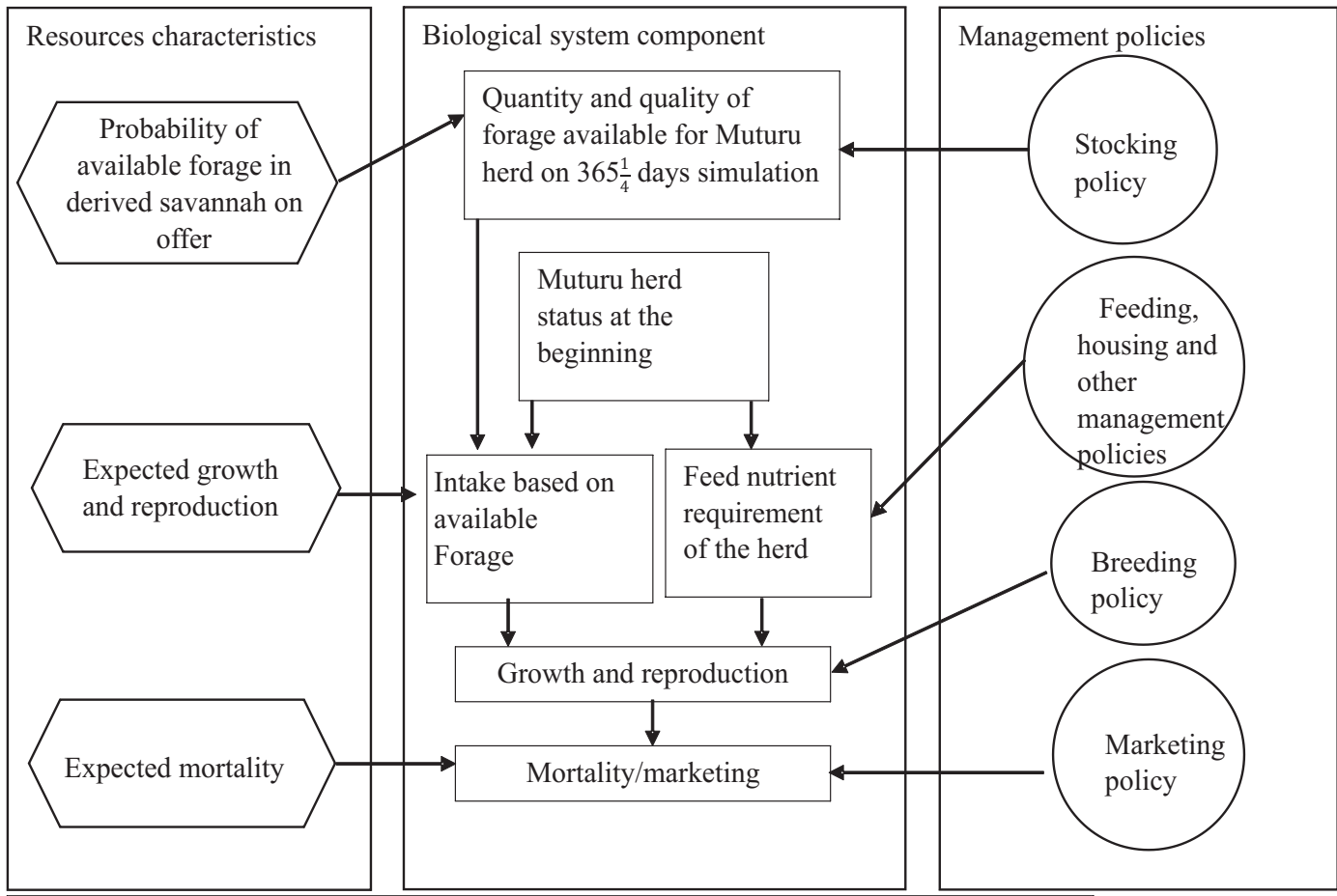

Figure 1. Components of Muturu herd biological system

A type dynamic, stochastic and non-optimizing model involving entity vectors of year-type input/out configuration was involved in the simulation process (Figure 2).

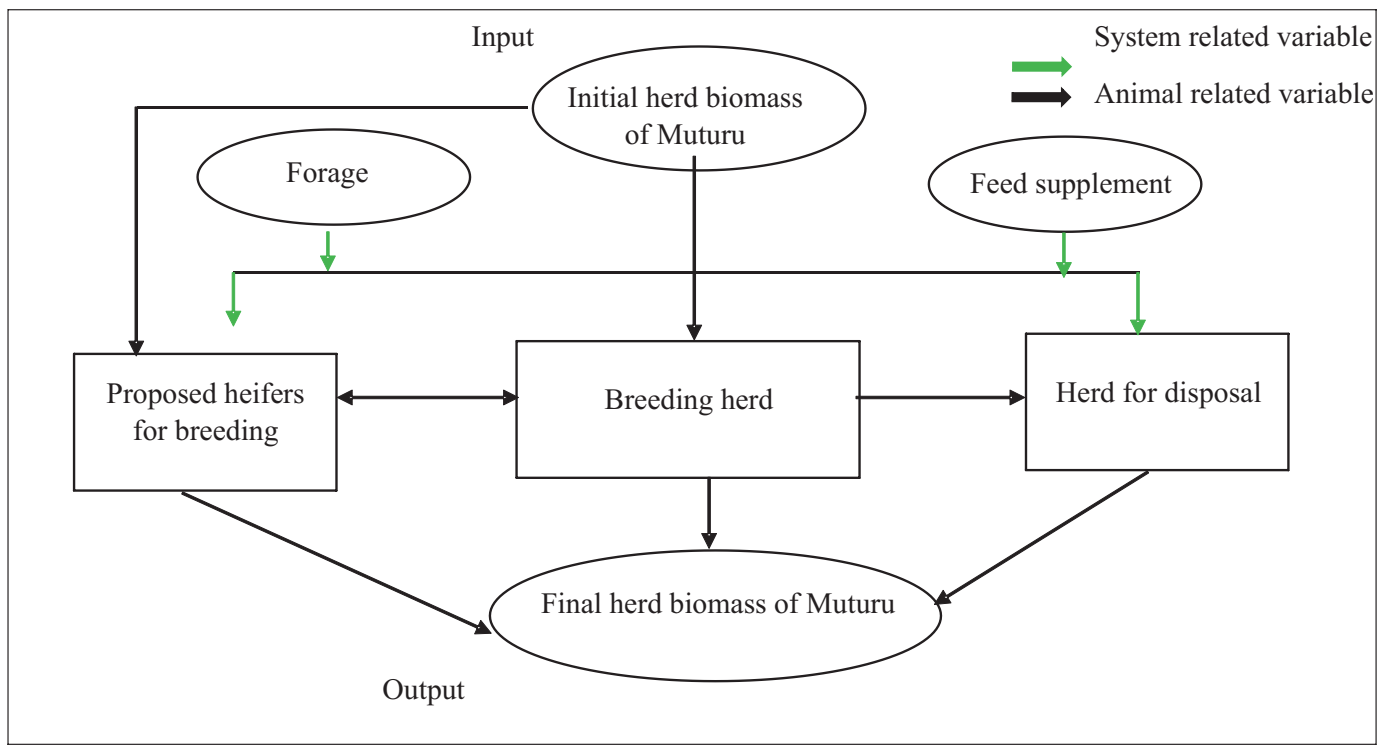

Figure 2. Input/output configuration of Muturu Sedentary Pastoral System 


\section{Herd simulation model of muturu cattle under sedentary pastoral farming}

There was experimental grazing orbit and the total number of 5-10 Muturu cattle per a grazing orbit was estimated. These were carried out for dry and wet season by casting of quadrat on grazing areas. The relative abundance of forage species was determined for the forage biomass (Nweze, 2017). Simulation model followed the computer package indicated in the data analysis using system-related and animalrelated variables (Table 2).

Table 2. Assumed correction-factor-multipliers for system-related variables of derived savannah

\begin{tabular}{lll}
\hline Variable & Wet Season & Dry Season \\
\hline Forage quantity $(\mathrm{Q})$ in dry matter basis $(\mathrm{t} / \mathrm{ha})$ & 2.50 & 0.50 \\
Digestibility of forage $(\mathrm{d})(\%)$ & 58.00 & 53.00 \\
Forage efficiency $\left(\mathrm{F}_{\mathrm{e}}\right)$ & 0.45 & 0.18 \\
Forage intake co-efficient $(\mathrm{a})$ & 0.60 & 0.40 \\
Grazing orbit distance $(\mathrm{D})(\mathrm{km} / \mathrm{day})$ & 5.00 & 10.00 \\
Digestibility of forage on offer $(\mathrm{d})(\%)$ & 58.00 & 53.00 \\
Crude protein of forage on offer $(\mathrm{CP})(\%)$ & 7.50 & 3.40 \\
Net energy for maintenance $\left(\mathrm{E}_{\mathrm{m}}\right)(\mathrm{MJ} /$ days) & 24.50 & 25.10 \\
Net energy for weight gain $\left(\mathrm{E}_{\mathrm{g}}\right)(\mathrm{MJ} /$ days) & 13.20 & 13.18 \\
\hline
\end{tabular}

Sources: Nweze (2017)

Weight of Muturu cattle as well as feed on offer within and outside the paddock was routinely determined on weekly basis. The Digestible feed nutrient based on dry matter on-offer expressed as

$$
\begin{gathered}
D_{n}=I_{m}-F_{m} \text {, where } D_{n}=\text { digestible dry matter feed consumed } \\
I_{m}=\text { feed intake of Muturu herd } \\
F_{m}=\text { feacal output from Muturu herd }
\end{gathered}
$$

In estimating simulated feed intake of Muturu herd on field grazing condition under sedentary pastoral system within the region, an expression represented below was used (Nweze, 2017).

$I=m(d, t) \cdot m(Q) \cdot m(D) \cdot m(t) \cdot m(x, t) \cdot m(p, t) \cdot q \cdot W_{t}^{-0.73}$

$\mathrm{I}=$ average daily forage intake of mature herd

$\mathrm{m}(\mathrm{d}, \mathrm{t})=$ digestibility of forage available on offer in day $(\mathrm{t})$

$\mathrm{m}(\mathrm{Q})=$ Quantity of forage available on offer in $\operatorname{day}(\mathrm{Q})$

$\mathrm{m}(\mathrm{D})=$ daily grazing time (number of hours per day(D))

$\mathrm{m}(\mathrm{t})=$ average ages of mature herd (months or year) $(\mathrm{t})$

$\mathrm{m}(\mathrm{x}, \mathrm{t})=$ physiological states of Muturu herd (pregnant or not pregnant $)(\mathrm{x})$

$\mathrm{a}=$ intake co-efficient of metabolic weight of Muturu herd

$\mathrm{W}_{\mathrm{t}}=$ Live weight of the Muturu herd

Tables 3 is the assumed correction factor multipliers for both the system related and animal related variables.

Table 3: Assumed Correction-factor-multipliers for animal related-variables

\begin{tabular}{ll}
\hline Variables & Values \\
\hline Considered average age of Muturu herds (E) (years) & 2.00 \\
Average weight of Muturu bull $(\mathrm{w})(\mathrm{kg})$ & 175.00 \\
Average weight of Muturu cow $\left(\mathrm{w}_{\mathrm{te}}\right)(\mathrm{kg})$ & 150.00 \\
Coefficient variation $\left(\mathrm{K}_{\mathrm{i}}\right)$ & 2.50 \\
Upper limit Live weight Muturu bull $\left(\mathrm{W}_{\text {maxb }}\right)(\mathrm{kg})$ & 180.00 \\
Lower limit Live weight Muturu bull $\left(\mathrm{W}_{\text {rninb }}\right)(\mathrm{kg})$ & 175.00 \\
Upper limit Live weight Muturu cow $\left(\mathrm{W}_{\text {mnxc }}\right)(\mathrm{kg})$ & 165.00 \\
Lower limit Live weight Muturu cow $\left(\mathrm{W}_{\text {in.c }}\right)(\mathrm{kg})$ & 135.00 \\
Voluntary dry matter intake $(\mathrm{I})(\mathrm{kg})$ & 5.60 \\
Potential weight gain $\left(\alpha_{\mathrm{p}}\right)(\mathrm{kg})$ & 0.25 \\
\hline
\end{tabular}

Sourecs: Nweze, 2017 


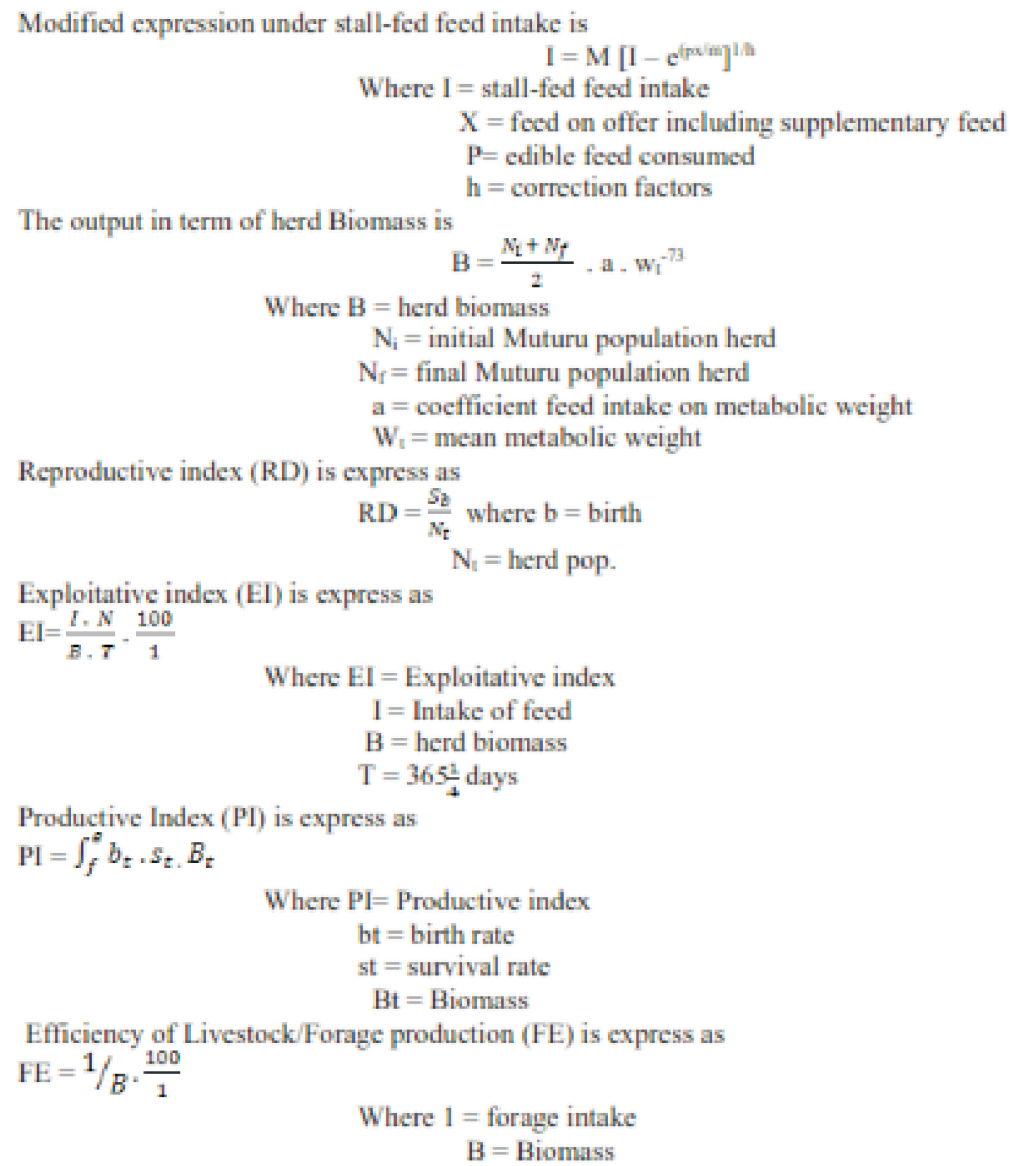

\section{Ranking of biological system}

There were six parameters used for the ranking of Muturu herd biological system. These include calving rate, survival rate, weight gain, productive and reproductive indices as well as livestock/forage efficiency of production. The maximum grade for each variable is 6 point making the cumulative grade to be 36 .

Percentage grade $=$

$$
\frac{\text { total grade }}{\text { Cumulative grade }} \times \frac{100}{1}
$$

\section{Data analysis}

Best linear unbiased estimate and prediction selection model (Henderson, 1993), SPSS 2014 and SAS (2002) as well as least square analysis of variance (Harvey, 1997) were used fordata analysis.

\section{Results and discussion}

The result in Table. 4 shows the sources of foundation stock and the distribution of Muturu cattle holders. A system of cattle ownership in the Southeast Nigeria exist in which wealthy individuals within rural communities give out their cattle to another person(s)to manage for them under a mutual agreement. Such agreement could stipulate the sharing formula for cow offspring and other leasing conditions for the animals. This cattle leasing system has given rise to two categories of Muturu cattle ownership namely Muturu Cattle Holder $(\mathrm{MCH})$ and Non-Pastoral Holder (NPH). The $\mathrm{MCH}$ constituted about 70 percent. While NPH were only 30 percent of the 


\section{Herd simulation model of muturu cattle under sedentary pastoral farming}

Muturu holders. The results in table 4 show that $\mathrm{MCH}$ only got 5 percent of their foundation stock through purchase. This shows that there were some challenges in sourcing dams and proven sires of Muturu for foundation stock within the region. The fact is that healthy cattle are hardly given out by their owners for sales even at a very high price, except if the owner is seriously in emergency or needed money urgently. The only animals worthy of sale are unhealthy cattle or old stocks that have ran out of breeding values. Another challenge in sourcing foundation stock is the difficulties in locating a breeding stock and transporting the stock to the farm due to bad road of the rural communities as well as absence of established proper Muturu cattle market in the zone. The NPH got higher values (30 percent) through purchase probably because some of them are willing to offer higher price. Muturu cattle sale is not usually on open market business, like other indigenous breed of cattle in Nigeria. The business is usually between individuals under on-farm arrangement. The Muturu cattle acquisition is by gift/donation from friends, relatives or in- laws during marriage or other events. Under such situations, the owner has the option of given out to the cattle out for other people to manage.

Table 4: Sources of muturu cattle foundation stock and holders' distribution

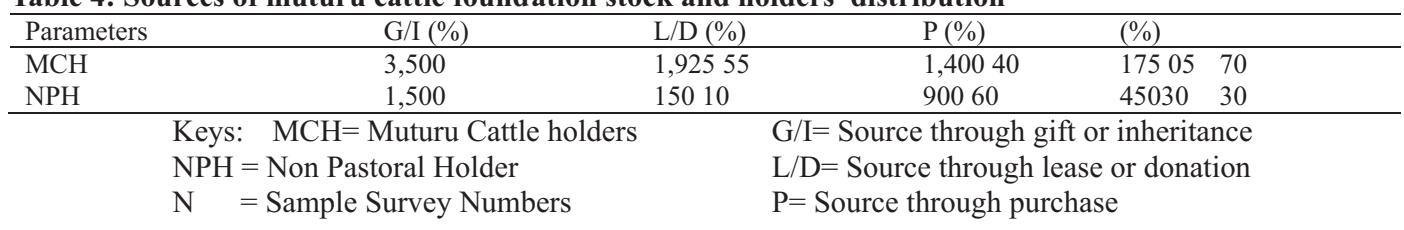

Table 5 represents Muturu herd productive performance. There were no significant differences $(\mathrm{CP}>0.01)$ for birth weight of male and female calves born on wet and dry season. However, the body weight of Muturu cattle at 12 and 24 months were significantly differences $(\mathrm{P}<0.05)$ for the wet and dry season duration. The superior body weight of the cattle during the wet season could be because of abundant forage species during the wet season (Table 3). This season provides higher feed resources for Muturu cattle than the dry season. Seasonal forage variability is one of the tropical challenges in cattle management (Agbola, 1982). Forage resources are serious issues especially with the prevailing global climate change affecting the ecosystem and the acute shortage of grazing land in the Southeast Nigeria.

Table 5: Muturu herd productive attributes under sedentary system in southeast, Nigeria

\begin{tabular}{lllll}
\hline Wet Season & Dry Season & & & \\
\hline Variables & Male & Female & Male & Female \\
Birth weight of calves (kg) & $10.45 \pm 2.3$ & $10.25 \pm 1.20$ & $9.29 \pm 1.20$ & $9.05 \pm 1.80$ \\
Body weight at 12 mnths (kg) & $92.24 \pm 5.60^{\mathrm{a}}$ & $85.20 \pm 3.80^{\mathrm{a}}$ & $78.50 \pm 10.50^{\mathrm{b}}$ & $75.20^{\mathrm{b}} \pm 10.28$ \\
Body weight at 24 mnths (kg) & $180.50 \pm 10.20^{\mathrm{a}}$ & $175.25 \pm 5.20^{\mathrm{a}}$ & $165.28 \pm 5.00^{\mathrm{b}}$ & $135.10 \pm 3.00^{\mathrm{c}}$ \\
Survival rate $\leq 2$ years (\%) & $85.00 \pm 0.50$ & $85.00 \pm 1.20$ & $80.25 \pm 1.50$ & $80.10 \pm 1.00$ \\
Survival rate 2 -5 years (\%) & $75.10 \pm 5.00$ & $73.10 \pm 5.00$ & $75.00 \pm 2.00$ & $73.10 \pm 5.00$ \\
Survival rate $\geq 5$ years (\%) & $73.00 \pm 5.00$ & $70.15 \pm 5.00$ & $73.00 \pm 5.00$ & $70.00 \pm 3.00$ \\
Calving rate 3 - 5 years (\%) & $20.00 \pm 5.00$ & $19.80 \pm 10.50$ & & \\
Calving rate 5 - 8 years (\%) & $44.50 \pm 8.00$ & $44.50 \pm 10.00$ & & \\
Calving rate $\geq 10$ years (\%) & $35.00 \pm 5.00$ & $35.00 \pm 10.50$ & & \\
\hline
\end{tabular}

$\mathrm{a}, \mathrm{b}, \mathrm{c}$ mean with different superscripts are significantly different $(\mathrm{p} \unlhd 0.05)$. 


\section{Nweze and Otuma}

Table 6 shows the birth rate of Muturu herd under field grazed, stall-fed and simulated values from year 2010 to 2019. There was significant difference $(\mathrm{P}<0.05)$ between the stimulated values and the values obtained from the two feeding managements. The simulated values were higher than the values from field grazed and stall-fed herd of cattle under the sedentary pastoral system suggesting that there was still unexploited potential in the pastoral system. The maximum number of cows that conceived and calving rate potentials was low showing untapped Muturu herd potentials in that regard. It revealed that good breeding management, adequate breeding record, proper male to female ratio and good feeding management could give room for increased birth by Muturu cows. Prevention of reproductive and other diseases that cause abortion and sterility in the herd could still improve the calving rate of Muturu herds (Nuru and Burvenendran, 1994 and Ezekwe, 2001).

Table 6: Least square mean for Muturu birth rate (\%) under herd-year grazing, stall -fed and simulated management

\begin{tabular}{llllll}
\hline Year & $\mathrm{N}$ & Grazing & Stall-Fed & Simulated & SEM \\
\hline LSM & 5,000 & $21.32^{\mathrm{b}}$ & $24.80^{\mathrm{b}}$ & 54.50 & 9.32 \\
2010 & 250 & $25.10^{\mathrm{a}}$ & $30.00^{\mathrm{a}}$ & $48.12^{\mathrm{a}}$ & 6.12 \\
2011 & 500 & $15.11^{\mathrm{c}}$ & $27.10^{\mathrm{b}}$ & $44.32^{\mathrm{a}}$ & 5.12 \\
2012 & 500 & $22.01^{\mathrm{b}}$ & $25.15^{\mathrm{b}}$ & $42.10^{\mathrm{a}}$ & 3.00 \\
2013 & 750 & $28.32^{\mathrm{b}}$ & $32.12^{\mathrm{ab}}$ & $61.42^{\mathrm{a}}$ & 3.01 \\
2014 & 500 & $21.10^{\mathrm{b}}$ & $30.15^{\mathrm{b}}$ & $47.10^{\mathrm{a}}$ & 4.32 \\
2015 & 450 & $24.32^{\mathrm{a}}$ & $27.18^{\mathrm{a}}$ & $45.15^{\mathrm{a}}$ & 4.00 \\
2016 & 500 & $27.16^{\mathrm{b}}$ & $31.32^{\mathrm{b}}$ & $51.00^{\mathrm{b}}$ & 5.50 \\
2017 & 550 & $18.20^{\mathrm{c}}$ & $25.00^{\mathrm{b}}$ & $42.00^{\mathrm{b}}$ & 6.20 \\
2018 & 420 & $16.32^{\mathrm{c}}$ & $20.18^{\mathrm{b}}$ & $48.10^{\mathrm{a}}$ & 5.00 \\
2019 & 580 & $27.23^{\mathrm{b}}$ & $30.12^{\mathrm{b}}$ & $59.12^{\mathrm{a}}$ & 3.25 \\
Wet season & 2,500 & $34.13^{\mathrm{c}}$ & $47.20^{\mathrm{b}}$ & $54.50^{\mathrm{a}}$ & 5.30 \\
Dry season & 2,500 & $20.25^{\mathrm{c}}$ & $30.15^{\mathrm{b}}$ & $48.32^{\mathrm{a}}$ & 5.00 \\
\hline
\end{tabular}

$\mathrm{a}, \mathrm{b}, \mathrm{c}$ mean with different superscript are significantly different $(\mathrm{p} \leq 0.05)$

Table 7 shows the mortality rate of herd under field-grazed, stall-fed and simulated values from 2010 to 2019 . The results show a relatively fit simulation model as there were no significant differences $(\mathrm{p}>0.01)$. The pattern of mortality rate, which was less than 20 percent, indicated no major health issue within the period. The reason could be due to small herd unit (Nweze, 2003). The small health unit of cattle could reduce the difficulty in health management operations, experience in a large herd (Osoyimi, 2008, and Agyemang, et al., 1996).

Table 7: Least square mean for Muturu herd mortality (\%) under herd-year grazing, stall-fed and simulated management

\begin{tabular}{llllll}
\hline Year & N & Grazing Condition & Stall-Fed Mgt & Simulated & SEM \\
\hline LSM & 5,000 & 10.25 & 10.70 & 10.50 & 0.20 \\
2010 & 250 & 16.18 & 10.00 & 12.25 & 4.11 \\
2011 & 500 & 13.10 & 12.65 & 12.20 & 1.32 \\
2012 & 550 & 10.28 & 11.70 & 11.25 & 1.50 \\
2013 & 750 & 18.15 & 15.00 & 15.70 & 3.30 \\
2014 & 500 & 12.00 & 11.00 & 11.10 & 1.25 \\
2015 & 450 & 10.10 & 10.25 & 11.25 & 1.00 \\
2016 & 500 & 10.15 & 10.10 & 11.00 & 0.56 \\
2017 & 550 & 19.15 & 18.00 & 18.32 & 1.32 \\
2018 & 420 & 13.00 & 10.25 & 12.85 & 5.32 \\
2019 & 580 & 10.25 & 10.18 & 10.75 & 0.78 \\
Wet season & 2,500 & 12.00 & 12.35 & 11.00 & 2.00 \\
Dry season & 2,500 & 11.85 & 12.25 & 11.15 & 2.32 \\
\hline
\end{tabular}




\section{Herd simulation model of muturu cattle under sedentary pastoral farming}

Table 8 represents biomass and productivity of the Muturu herd. The results show significant difference $(\mathrm{P}<0.05)$ among the herd biomass and other parameters of productivity under field grazed, stall-fed management and the simulation model. The simulated livestock biomass-change value was lowest (193.20 tons) among the three values, followed by field grazed (204.47 tons). While the stall-fed herd had the highest values (1230.20 tons), indicating inherent discrepancy in the method of feeding system. The stall-fed system appeared to be a more reliable method of feeding cattle than the field-grazed system (Nweze, 2013). The grazing management under sedentary system in the region appeared not to provide adequate feeding arrangement for Muturu cattle within the region. There are a lot of challenging cattle production management issues such seasonal variation of forage resources (Agbola, 1982), improper breeding and breeding record (Ezekwe, 2017), lack of modern cattle facilities (Nweze, 2017) and poor record of the animals. These discrepancies in the biological system indicators show a great departure of sedentary pastoral farming from the best global practice of cattle production (Ochere and Nuru, 1985). This also was evidenced in livestock/forage efficiency of production that was very low $(13.20 \%, 15.32$ percent and $17.35 \%$ for field grazed, stall-fed and simulated values respectively). Even though the survival rates of the Muturu herd under the system were very high, the reproductive and productivity indices were still below average, indicating ineffective production process. Similar low productive capacity of tropical forage species has been reported by scholars (Agbola, 1977; Awogbade, 1980; Powell, 1986).

Table 8: Muturu herd biomass and productivity under field grazing, stall-fed and simulated management

\begin{tabular}{|c|c|c|c|}
\hline Parameters & Grazing & Still-Fed & Simulated \\
\hline Livestock initial biomass (tons) & $186.25 \pm 14.10 \mathrm{c}$ & $478.15 \pm 15.00 \mathrm{a}$ & $219.72 \pm 14.00$ \\
\hline Livestock initial biomass (tons) & $390.72 \pm 15.00 \mathrm{c}$ & $1230.20 \pm 15.00 \mathrm{a}$ & $484.92 \pm 15.00 b$ \\
\hline Livestock biomass change (tons) & $204.47 \pm 15.00 b$ & $752.05 \pm 15.00 \mathrm{a}$ & $193.20 \pm 3.50 \mathrm{c}$ \\
\hline Muturu birth weight per head (kg) & $13.50 \pm 1.50$ & $15.22 \pm 3.20$ & $14.15 \pm 3.50$ \\
\hline Muturu body weight at 24 months $(\mathrm{kg})$ & $164.98 \pm 10.72 \mathrm{c}$ & $191.37 \pm 15.00 \mathrm{a}$ & $180.52 \pm 17.00 \mathrm{~b}$ \\
\hline Muturu monthly weight gain (kg) & $6.98 \pm 3.25$ & $8.70 \pm 2.00$ & $7.20 \pm 2.50$ \\
\hline Muturu calving rate $(\%)$ & $29.19 \pm 5.10 \mathrm{c}$ & $37.16 \pm 5.00 b$ & $56.44 \pm 10.00$ \\
\hline Muturu surviving rate $(\%)$ & $85.74 \pm 8.20$ & $82.09 \pm 4.20$ & $88.90 \pm 10.20$ \\
\hline Muturu reproductive index $(\%)$ & $28.53 \pm 2.00$ & $29.00 \pm 1.20$ & $35.52 \pm 5.20$ \\
\hline Forage productivity index $(\%)$ & $28.53 \pm 2.15$ & $30.40 \pm 4.50$ & $28.50 \pm 3.20$ \\
\hline Livestock/Forage efficiency of production & $13.20 \pm 1.00$ & $15.32 \pm 3.50$ & $17.35 \pm 3.50$ \\
\hline
\end{tabular}

$\mathrm{a}, \mathrm{b}, \mathrm{c}$ mean with different superscripts are significantly different $(\mathrm{p} \leq 0.05)$.

Table 9 represents herd biomass and productive ranking. There was low rank on both field-grazed and stall-fed management with 25 percent and $33.33 \%$ for field-grazed and stall-fed management respectively, indicating inappropriate cattle management system. The survival rate of the Muturu herd had good grade (4 point in both the field grazed and stall-fed management system). The field grazed cattle has a very low grade because there was poor management already observed within the sedentary pastoral system. This means that there is urgent need to change the system of cattle production if Muturu cattle should continue to strive in the region. The sustenance of Muturu breed is necessary, as Muturu breed is one of the indigenous breed adapted to environment of the region and all effort should be made to prevent the extinction of cattle in the region. 


\section{Nweze and Otuma}

Table 9: Herd biomass and productive ranking of Muturu on field-grazed and stall-fed management.

\begin{tabular}{|c|c|c|}
\hline Parameters & Field Grazing Grade & Stall-Fed Grade \\
\hline Calving rate $(\%)$ & 1.00 & 2.00 \\
\hline Survival rate $(\%)$ & 4.00 & 4.00 \\
\hline Body weight gain (\%) & 1.00 & 2.00 \\
\hline Reproductivity index (\%) & 1.00 & 1.00 \\
\hline Productivity index $(\%)$ & 1.00 & 2.00 \\
\hline Livestock/forage efficiency of production & 1.00 & 1.00 \\
\hline Total grade & 9.00 & 12.00 \\
\hline Percentage grade & 25.00 & 33.33 \\
\hline \multicolumn{3}{|c|}{ Cumulative weighing point $=36$, maximum grade $=6$ point } \\
\hline $\begin{array}{ll}1=\text { very poor } & 2=\text { poor } \\
4=\text { good } & 5=\text { very good }\end{array}$ & $\begin{array}{l}3=\text { fair } \\
6=\text { excellent }\end{array}$ & \\
\hline
\end{tabular}

\section{Conclusion}

The herd simulation model of Muturu cattle showed that sedentary pastoral system on Savannah, South East Nigeria was defective cattle production system. There was generally low ranking of Muturu herd productive capacity under the pastoral system. Therefore, there is a need to change the system with improved modern production system to enhance Muturu herd population and productive capacity.

\section{References}

Adegbola, A. A. 1982. Forage resources and beef production in Nigeria. Proc. Nat. Conf. of beef prod. July 1982, Zaria pp 137-167.

Agymang, K., Dwinger, R.H., Grieve, A.S. and Little, D.A. 1996. Productivity and health parameters of small ruminant in village Gambia. Bulletin of Anim. Health and prod in Africa 39. 29-135.

Apata, T.A., Folayan, A., Apata, O.M. and Akinlu, N. 2011. The economic role of Nigerian Subsistent Agriculture in the transition process; Implication for Rural Development. $8^{\text {th }}$ Ann. Conf. Agric Econ. Soc. Warrick University pp 18-20.

Andiezeje, W.S.K. L. 1982. Experimental studies on trophic relationship of terrestrial Animal. In secondary productivity of terrestrial Ecosystem; principle and method. (Ed). Prefrusewics and Krakow pp 477-495.
Awogbade, M. 1980. Livestock Development and Range use in Nigerian Cattle. In future of pastoral people, proc. Inst. Develop studies, August 4-8. Nairobi. pp 325-333.

Ezekwe, A.G. (2001). Preliminary observation on gestation length age at first calling and birth weight of Muturu Cattle. J. Anim. Prod. 26.16.

Fricke, N. 1993. In cattle production in Northern Nigeria National Herd and Social Development (Ed) Weiham pp 104.

Harvey, W.R. 1977. Users Guide for Least Square and Maximum Likelihood of computer program. Ohio.

Henderson, C.R. 1993. Best Linear Unbiased Estimate and Prediction in selection model. Biometrics 31 (1) 423-447.

Konandreas, P. and Anderson, F. M. 1982. Cattle herd dynamics: An integer and stochastic model for evaluating production alternatives. Research paper No 2. Adisababa $\mathrm{p}$ 253.

Krumel, J. R., Neil O. and J. Makin 1986. Regional Environment Simulations of African Cattle herd societies. Human Ecology pp 117-130.

Lawson, T. C. 1980. Agro-climate. In Agro metrology. Mac Milian (Ed). USA pp 37-45

Nuru, S., Buruvendran 1994. The indigenous cattle breed, problem and potential. In evaluation of Large 
Ruminant for Tropics. (Ed) Frockanton. Queensland. pp5

Nweze B. O. 2017. The use of Integer and stochastic model in pastoral farming and Animal productivityIn Nigerian pastoral farming and pasture production. Dika Pub. Abakaliki, Nigeria pp 136-200.

Nweze B. O. 2014. Effect of seed and vegetable proagules on pasture establishment. Greener J. Agricsci vol 4(2) pp 27-33.

Nweze, B. O. 2012. Effect of stall-fed management on growth performance of pure and cross-bred. Muturu Cattle. World J. Engineering, Pure and applied sci. $2012(2) 7$.

Nweze, B. O., Alaku S. O. and Omeje S. I. 2012. Comparative indices of Muturu, N'dama and their crossbred calves under field grazed and stall fed condition. Proc. Anim. Sci. Assoc. Nig. 16-19 September 2002. Abeokuta pp236-238.

Nweze, B. O., Ekwe O.O., Alaku S. O. and Omeje S. I. 2012. Cattle breed and their cross bred range grazing management. World J. Med. Reseach. 2012:2:1.

Nweze B. O. 2008. Cattle production system. In Manual of Agric. Practical. (Ed) Ezike and Okorie EBSU,AbakalikiNig pp 17-21.

Nweze, B. O. 2006. Zoometrical measurement of Muturu cattle kept under range management in Derived Savannah. Trop. J. Anim. Sci Vol.1.1-5.

Nweze B. O., Otuma, M. O., Ekwe O. O., Oga U. O. 2003. Agropastoral system in humid tropics. A case of Rice-Muturu integrated farming practice in Ebonyi state. $28^{\text {th }}$ Ann. Cont. Anim. Sci. Assoc. Nig. 17-19 Sept. Maiduguri Nigeria pp 139141.
Nweze B. O., Alaku S. O. and Omeje S. I. 2002. Comparative indices of Muturu, N'dama and their cross bred calves under field grazed and stallfed. Condition. Proc. Anim. Sci Assoc. Nig 16-19. Sept. Abeokuta, Nigeria pp 305-309.

Nweze B. O. 2003. The grazing pattern of Muturu cattle under Range System. Nig. J. Anim. Prod. 30(1):57-61.

Nweze, B. O., Ekwe, O. O. and Ewa V. E. 1999. Rice-Muturu Agro-pastoral farming in Ebonyi state, Nigeria. Proc. $26^{\text {th }}$ Ann. Conf. NSAP 21-25 March, Ilorin, Nigeria. Pp487-489.

Osiyimi, T. I. O. 2008. The herd health management in Nigeria. New approach. Proc. Beef cattle prod. July 2008 Zani, Kaduna. PP 468485.

Payne W. J. A. 1990. Cattle husbandry. In an introduction to Animal husbandry in Tropics. $4^{\text {th }}$ (Ed). Longman pp 197-421.

Powell J. M. 1986. A case study of cattle farming in Nigeria. J. Exp. Agric. 22: $15-18$.

SAS (2002). SAS statistics user's guide. Version 9.1. SAS Institute of North Carolina USA.

SPSS (2014). IBM statistics SPSS Institute Chicago Ib 60606-6412, USA. Vol.2.0.2014.

Umoh. E. J. 1996. Sustaining livestock production in Nigeria with local feed. $21^{s t}$ Ann. Cof. Nig. Soc. Anim. Prod. March 25-29, Uyo, Nig. Pp226-236.

Umunna, N. N. and Iji, P. A. 1993. The natural feed resources for ruminant animals. In forage prod. and utilization in Nigeria. National Livestock Production Division, Nigeria. June 1993.

Received: $20^{\text {th }}$ August, 2020 Accepted: $19^{\text {th }}$ November, 2020 